\title{
Multi-modal Approach for Benthic Impact Assessments in Moraine Habitats: a Case Study at the Block Island Wind Farm
}

\author{
Marisa L. Guarinello ${ }^{1}$ (D) $\cdot$ Drew A. Carey ${ }^{1}$ \\ Received: 3 May 2019 / Revised: 9 August 2020 / Accepted: 10 August 2020 / Published online: 19 August 2020 \\ (C) The Author(s) 2020
}

\begin{abstract}
Benthic assessment techniques utilized in soft sediment areas are of limited utility in glacial moraine habitats that are structurally complex and largely composed of hard substrata. We present a multi-modal approach consisting of multibeam bathymetry, video, and still imagery that collectively provides the knowledge base necessary to perform impact assessments in these habitats. Baseline and post-construction surveys were conducted adjacent to the Block Island Wind Farm to develop and test these methodologies within the context of offshore wind development, specifically for detecting and documenting anchoring-related impacts to moraine habitats. Habitat data were evaluated using the substrate and biotic components of the national classification standard, the Coastal and Marine Ecological Classification Standard, recommended by federal regulators, with modifications to present results in terms of predicted vulnerability to disturbance. Habitats near the wind farm were diverse and patchy, ranging from rippled gravelly sand to continuous cobble/boulder fields with high biotic cover. Anchor furrows were detected in moderate value habitats in bathymetric and video data. The multi-modal survey approach tested at the Block Island Wind Farm and presented here is now specifically recommended by federal agencies and is being used to inform efforts currently underway to map and assess benthic habitats for a number of U.S. projects seeking federal permits.
\end{abstract}

Keywords Moraine $\cdot$ Impact assessment $\cdot$ Habitat mapping $\cdot$ CMECS $\cdot$ Offshore wind

\section{Introduction}

With increasing recognition of the consequences of climate change and the need to reduce dependence on fossil fuels, countries around the world are investing significant resources in developing renewable energy supplies (Barrie et al. 2014; Szulecki et al. 2016; Voormolen et al. 2016). The wind energy industry continues to grow globally with an increasing share of new installations in offshore waters (Global Wind Energy Council [GWEC] 2019). Offshore developments began in Europe (Bilgili et al. 2011) and dominated the market for decades (Firth et al. 2016), and, although the majority of existing

Communicated by Paul A. Montagna

Electronic supplementary material The online version of this article (https://doi.org/10.1007/s12237-020-00818-w) contains supplementary material, which is available to authorized users.

Marisa L. Guarinello

marisa@INSPIREenvironmental.com

INSPIRE Environmental, 513 Broadway, Newport, RI 02840, USA offshore wind installations remain in Europe, markets in Asia and North America are growing rapidly (GWEC 2019). Indeed, development plans and environmental studies are now underway along the United States (U.S.) Atlantic outer continental shelf at more than a dozen federal lease areas, managed by the U.S. Bureau of Ocean Energy Management (BOEM).

Addressing environmental concerns and studying the effects of offshore wind farms on marine habitats and resources is paramount to the success of each development and the industry as a whole (Barrie et al. 2014). Offshore wind installations represent a rapidly growing contribution to ocean sprawl, i.e., the proliferation of artificial structures in coastal and offshore environments (Firth et al. 2016). Among concerns related to ocean sprawl most pertinent to offshore wind farms are interruptions to marine population connectivity (Bishop et al. 2017) and alteration of sedimentary environments and biotic communities (Heery et al. 2017). Research on how offshore wind farms affect marine environments has largely taken place in northern Europe and established monitoring programs there were generally designed to meet regulatory benchmarks across ecosystem components rather than to address targeted questions related to ecosystem function (Lindeboom et al. 2015; 
Wilding et al. 2017). At this stage, it is undisputed that wind farms change the local environment and they have both potentially positive and negative effects on the marine environment (Wilson et al. 2010; Lindeboom et al. 2015).

It is particularly important to understand the effects of offshore wind development on the seafloor, which contributes significantly to ecosystem services globally (Costanza et al. 1997; Liquete et al. 2013; Dannheim et al. 2019). Accurate seafloor habitat maps are essential for developers to appropriately site and design wind farms (Barrie et al. 2014), to satisfy environmental assessment requirements, and for scientists to have a baseline from which to monitor and measure change (Shields et al. 2009; Barrie et al. 2014; e.g., LaFrance et al. 2014; Pearce et al. 2014; Schlappy et al. 2014; Carey et al. 2019). A review of European studies primarily conducted in soft seafloor settings concluded that knowledge on changes to benthic ecological functioning due to offshore marine renewable operations is limited and will require hypothesis-driven research combined with ecological modeling (Dannheim et al. 2019). In the U.S., developers are required by BOEM to submit a benthic assessment as part of the Construction and Operation Plan for their planned development (BOEM 2019). Further, certain benthic habitats are designated as essential fish habitat (EFH) for many fish and shellfish species and review of the potential construction impacts on these species through permanent and temporary disturbance of their habitat is a critical component of the regulatory permitting process. The National Oceanic and Atmospheric Administration Fisheries' Habitat Conservation Division (NOAA Habitat) is responsible for conducting an official consultation on the potential impacts of proposed wind farm developments on EFH and providing conservation and mitigation recommendations. The consultation process is greatly aided by accurate and well-development benthic habitat maps (NOAA Habitat 2020). In fact, benthic habitat mapping inadequate for NOAA to properly assess impacts to EFH (NOAA 2019) contributed to a halt in the permitting process for the Vineyard Wind project. Vineyard Wind was the first wind farm to enter the federal permitting process, with others in the Rhode Island-Massachusetts Wind Energy Area close behind.

Within the Rhode Island-Massachusetts Wind Energy Area, hard bottom habitats often found associated with glacial moraine deposits are habitats of concern for NOAA, as well as for Rhode Island and Massachusetts marine resource agencies that also review wind farm developments. These moraine habitats are physically complex ranging from scattered cobbles with small amounts of biotic cover to continuous cobble and boulder fields supporting diverse and abundant biological resources and are limited in their distribution in the region (Poppe et al. 2014). Moraines are critical habitats for ecologically and economically important taxa, such as American lobster (Wahle and Steneck 1991), juvenile Atlantic cod (Clark and Green 1990; Gotceitas and Brown 1993), and longfin squid (Griswold and Prezioso 1981; Roper et al. 1984). Because these habitats provide stability and physical complexity that may be difficult to restore, they are a focal point for regulatory conservation recommendations and mitigation negotiations.

Understanding the distribution hard bottom habitats before construction and monitoring effects post-construction will become increasingly important as more renewable energy structures are built on or near these habitats (Shields et al. 2009; Schlappy et al. 2014; NOAA 2019). However, benthic sampling devices (grab samples) and paradigms for consistently understanding recovery (successional stage theory, Pearson and Rosenberg 1978; Rhoads and Boyer 1982; Rhoads and Germano 1982) traditionally used in soft sediment environments are of little use in hard bottom areas (Taylor and Wilson 2003; Sheehan et al. 2010). Use of high-resolution multibeam echosounder (MBES) data and high-resolution ground-truth imagery has been recommended for mapping these habitats (Kenny et al. 2003; Diaz et al. 2004; NOAA Habitat 2020) and has been used to characterize hard bottom and mixed habitats before construction at offshore renewable energy sites in the UK (Sheehan et al. 2010; Pearce et al. 2014), Norway (Schlappy et al. 2014; Saskov et al. 2015), and the U.S. (Carey et al. 2019).

Hard bottom moraine habitats serve as key resources for ecologically and economically important fish and invertebrates and the potential impacts of offshore wind construction on these habitats are not well understood. We present a multimodal approach consisting of multibeam bathymetry, video, and still imagery that collectively provides the knowledge base necessary to perform impact assessments in these areas. Baseline and post-construction surveys were conducted adjacent to the first offshore wind farm in the U.S., the Block Island Wind Farm (BIWF), to develop and test these methodologies (1) for assessing moraine habitats for impact assessments, using the BIWF as a case study, and (2) for detecting and documenting anchoring-related impacts to habitats and biota. Notably, this study is the first of its kind in the U.S., characterizing and detecting acute and spatially limited disturbances to moraine habitats due to offshore wind construction.

\section{Methods}

Consideration of moraine habitats in siting, seafloor assessments, and agency consultation was critical for successful development of the BIWF, which is located within Rhode Island state waters in depths ranging from approximately 15 to $30 \mathrm{~m}$. The five-turbine BIWF was sited to avoid construction in moraine habitats and its southernmost wind turbine generator (WTG) is located near one of several shallow ridges south of Block Island formed by glacial moraine deposits on Southeast Ledge. Because of the potential for construction barges to anchor in this area, the construction permit issued 
by federal and state regulators (U.S. Army Corps of Engineers [USACE] permit \#NAE-2009-789) required the developer, Deepwater Wind LLC, to minimize impacts to hard bottom habitats to the greatest extent practicable and to monitor and assess effects and recovery of these habitats. Deepwater Wind's Anchor Plan delineated the cobble/boulder habitat area known at the time, a maximum work area in which anchors would be permitted, and targeted maximum anchoring extents around each WTG (Fig. 1).

We used an integrated multi-modal approach comprised of MBES, towed video footage, and plan view (PV) still imagery to collect data on seascape (100-1000 s of meters), geoform (10 s of meters), and granular $\left(\sim 1 \mathrm{~m}^{2}\right)$ scales. Our survey design included a staggered implementation, with MBES data collected first so that preliminary processed data could be used to guide video and PV imagery collection. These methodologies are designed to detect changes that may result from construction and placement of anchors, such as changes in seabed volume (scouring, deposition), changes to the diversity and abundance of benthic communities, and decrease in hard bottom habitat (McCann 2012; Shumchenia et al. 2012). To detect and account for natural variability within habitats found in the impact area where anchoring was permitted, we included areas to the north and south as controls (Fig. 1).

\section{Field Collection}

We conducted three surveys: (1) a pre-construction baseline survey in late June and early August 2015 (hereafter referred to as Summer 2015), (2) a post-construction survey in March 2016 to detect anchor activity, and (3) a postconstruction survey in August 2016. For the Summer 2015 baseline survey, a stratified random sampling design was used to select target PV stations within equal-area sampling grids in the construction area and in the two control areas. Video transects were selected to provide broad coverage of each area and to capture gradients in seafloor topography. For the March 2016 survey, we used as-built coordinates of anchor locations provided by Deepwater Wind and MBES data to inform positioning of video transects and PV stations. The August 2016 post-construction survey was designed to determine if disturbance features identified in the March 2016 survey showed indications of recovery and to re-assess control areas compared to the anchoring impact area. Additionally, video and PV camera survey locations were modified in real-time to collect data at disturbance features detected in MBES data.

A R2Sonic 2022 MBES operating at $200 \mathrm{kHz}$ with a 50microsecond pulse was used to collect bathymetric data across

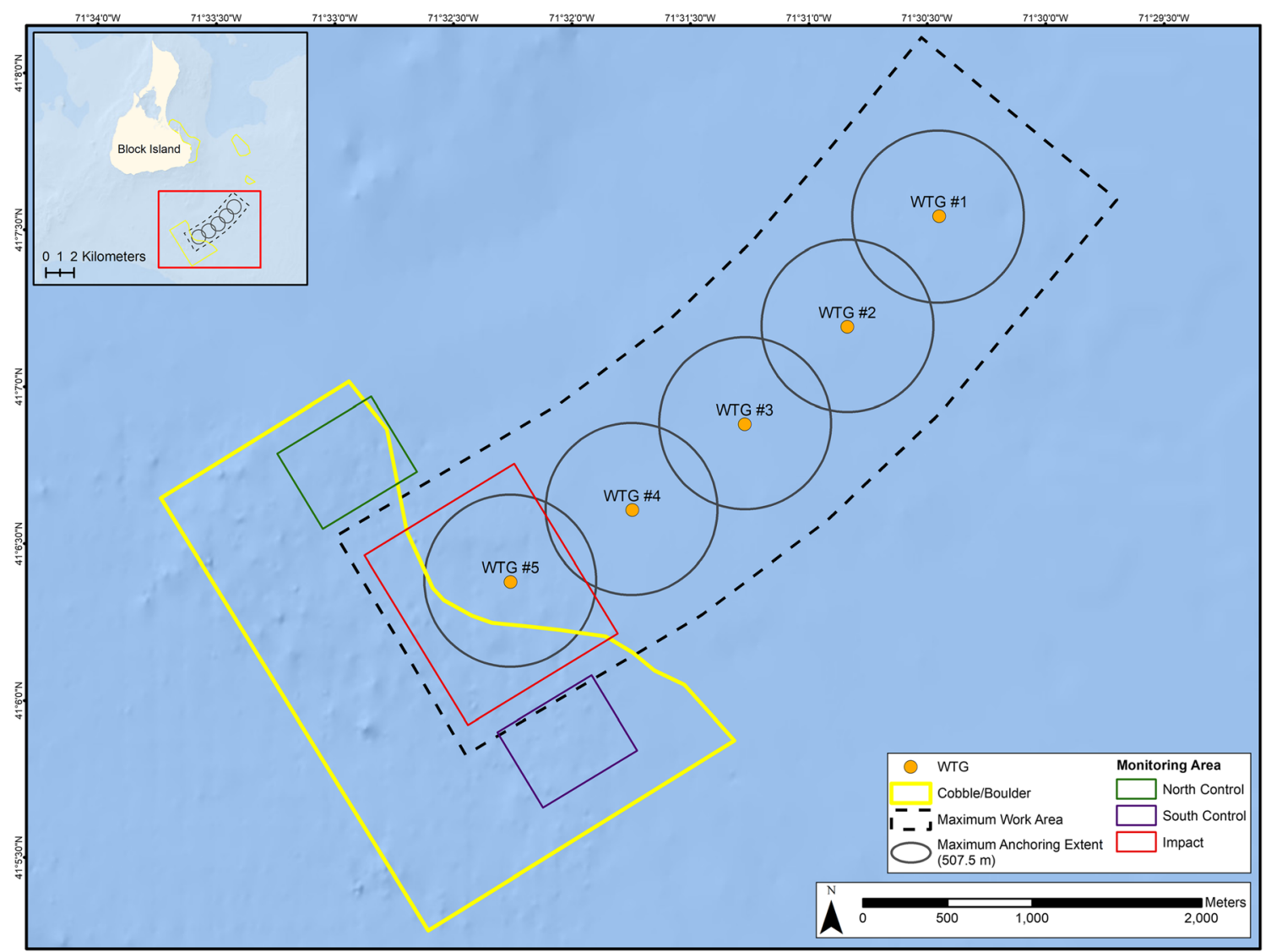

Fig. 1 Permit-approved Anchor Plan for the BIWF, the area of cobble/boulder known at time of permitting, and monitoring areas established for this study 
the approximately $2.5 \mathrm{~km}^{2}$ study area. Depth, motion, and heading were pulse-per-second time-stamped. Navigation was performed using a Hemisphere VS-330 RTK GPS with a horizontal accuracy of approximately $1.0 \mathrm{~cm}$ and vertical accuracy of approximately $2.0 \mathrm{~cm}$. To achieve greater than $100 \%$ coverage of the seafloor, overlapping lanes were used and transect spacing and swath limits were established to optimize swath sounding quality and to minimize data artifacts; observed sea state and water column stratification were considered in setting limits. The MBES transducer depth below the water surface was calibrated and monitored throughout the survey. Several patch tests were conducted during each survey to allow computation of angular offsets between MBES system components. The system was calibrated for local water mass speed of sound by performing sound velocity profile casts at frequent intervals.

Video imagery was collected using a towed video sled system consisting of a lightweight aluminum frame, Outland Technologies' high-resolution low light color camera, two wide-angle 250-watt lights with variable output control, and scaling lasers. A GoPro Hero Black video camera was mounted on top of the video sled and recorded HD video and auto-captured still frames every $10 \mathrm{~s}$. Video footage was obtained with the vessel operating in drift mode, at speeds ranging from 0.5 to 1 knots ( 0.25 to $0.5 \mathrm{~m}$ per second). Video imagery was monitored in real-time and the vessel's hydraulic winch was adjusted to achieve optimal sled height and video quality. A Hemisphere VS-330 RTK GPS mounted to the vessel's A-frame and the amount of cable spooled out plus layback angle were used to determine video position. Due to tide and sea conditions, the orientations of several planned transects were modified in the field during each survey. A total of 47 video transects ranging from 54 to $1049 \mathrm{~m}$ were sampled (12 in Summer 2015, 10 in March 2016, and 25 in August 2016).

An Ocean Imaging ${ }^{\circledR}$ Model DSC24000 PV underwater camera system equipped with a Nikon D-7100 camera, strobe light, scaling lasers, and bounce trigger was used to collect PV images of the seafloor surface. The position of each image captured was recorded using a Hemisphere VS-330 RTK GPS mounted to the vessel's A-frame. PV images were collected from a total of 130 stations (56 stations in Summer 2015, 36 stations in March 2016, and 38 stations in August 2016); three replicate images were collected at each sampling station. Replicates were located within an average of 3.5 to $5 \mathrm{~m}$ from mean station locations. In the August 2016 survey, 30 single camera drops along 5 transects running perpendicular to anchor furrows were also collected.

Table 1 CMECS classification levels used in analysis and classification examples

\begin{tabular}{|c|c|c|c|}
\hline CMECS term & $\begin{array}{l}\text { Scale of } \\
\text { classification }\end{array}$ & Classification example & BOEM guideline \\
\hline \multicolumn{4}{|l|}{ Substrate component } \\
\hline Substrate origin & Site & Geologic substrate & \\
\hline Substrate subclass* & Video; plan view & $\begin{array}{l}\text { Coarse unconsolidated } \\
\text { substrate }\end{array}$ & $\begin{array}{l}\text { - Identification of rock outcrops and boulders* } \\
\text { - Identification of bedforms* }\end{array}$ \\
\hline Substrate group* & Video; plan view & Gravel mixes & - Classification of CMECS sediment type* \\
\hline Substrate subgroup* & Plan view & Gravelly sand & $\begin{array}{l}\text { - Grain size analysis* } \\
\text { - Classification of CMECS sediment type* }\end{array}$ \\
\hline Surface pattern modifier & Video; plan view & Irregular & - Identification of bedforms* \\
\hline \multicolumn{4}{|l|}{ Biotic component } \\
\hline Biotic setting & Site & Benthic/attached biota & - Characterization of benthic habitat attributes* \\
\hline Biotic class & Video; plan view & Aquatic vegetation bed & $\begin{array}{l}\text { - Classification to CMECS biotic class } \\
\text { - Characterization of benthic habitat attributes* }\end{array}$ \\
\hline Biotic subclass & Video; plan view & Attached fauna & $\begin{array}{l}\text { - Identification of potentially sensitive seafloor habitat* } \\
\text { - Classification to CMECS biotic subclass } \\
\text { - Characterization of benthic habitat attributes* }\end{array}$ \\
\hline Biotic group & Video; plan view & Attached filamentous algae & $\begin{array}{l}\text { - Classification to CMECS biotic group } \\
\text { - Characterization of benthic habitat attributes* }\end{array}$ \\
\hline Biotic community for primary biotic group & Video; plan view & Attached Didemnum & - Characterization of macrofaunal community \\
\hline Biotic group percent cover modifier & Video; plan view & Moderate $(30$ to $<70 \%)$ & - Characterization of macrofaunal community \\
\hline $\begin{array}{l}\text { Co-occurring element modifier (applied to } \\
\text { biotic group, community, percent cover) }\end{array}$ & Video; plan view & - Attached Bugula & - Characterization of macrofaunal community \\
\hline Associated taxa modifier & Video; plan view & Asterias & - Characterization of macrofaunal community \\
\hline
\end{tabular}

*NOAA Habitat Recommendations: CMECS substrate classification level included in NOAA Habitat Recommendations \& BOEM Guideline also included in by NOAA Habitat's Recommendations 
Table 2 Habitat classification groups derived from CMECS analysis of video

\begin{tabular}{lll}
\hline Habitat group & Group description from CMECS & Short description \\
\hline $\mathrm{W}$ & Cobble, smooth, high biotic cover & Cobble/boulder; high biotic cover \\
$\mathrm{X}$ & $\begin{array}{c}\text { Cobble, smooth or irregular, medium or sparse } \\
\text { biotic cover (algae and sponges) }\end{array}$ & $\begin{array}{c}\text { Cobble/boulder; med biotic cover } \\
\text { Y }\end{array}$ \\
Sandy gravel, irregular, medium or sparse biotic & $\begin{array}{c}\text { Sandy gravel with patchy cobbles; } \\
\text { patchy biotic cover }\end{array}$ \\
$\mathrm{Z}$ & $\begin{array}{c}\text { Gravelly sand, irregular or rippled, trace to sparse } \\
\text { biotic cover }\end{array}$ & $\begin{array}{c}\text { Rippled gravelly sand with occasional } \\
\text { cobbles; low biotic cover }\end{array}$ \\
Anchor furrow & Gravel, boulder/cobble, no to trace biotic cover & $\begin{array}{c}\text { Anchor furrow, cobbles and boulders in } \\
\text { mixed sand dragged into linear array }\end{array}$ \\
\hline
\end{tabular}

\section{Analysis}

MBES bathymetric data were processed using HYPACK HYSWEEP® software. Data processing included application of tide corrections using data from the RTK GPS, the NOAA Newport Tide Station (\#8452660), and an InSitu ${ }^{\circledR}$ moored gauge installed on a mushroom anchor at the survey area; adjustment of beam orientation using patch test calibrations; soundings corrections; and removal of soundings associated with water column interference (e.g., fish, suspended debris). Data artifacts associated with refraction remaining in the bathymetric surface model are relatively small $(\sim 5$ to $10 \mathrm{~cm}$ ). Data were reduced to a cell (grid) size of $3 \times 3 \mathrm{ft}$. $(0.91 \times 0.91 \mathrm{~m})$ by calculating and exporting the average elevation for each cell in accordance with USACE recommendations (USACE 2013). A combination of ESRI ArcMap
Fig. 2 Physical and biological habitat relationships in PV and video imagery used to develop video habitat groups and the physical habitat stability modifier: a habitat groups derived from substrate and biotic classifications of baseline video data collected in Summer 2015 and b physical habitat characteristics classified from PV images used to delineate a spectrum of stability/mobility, with total percent macrobiotic cover
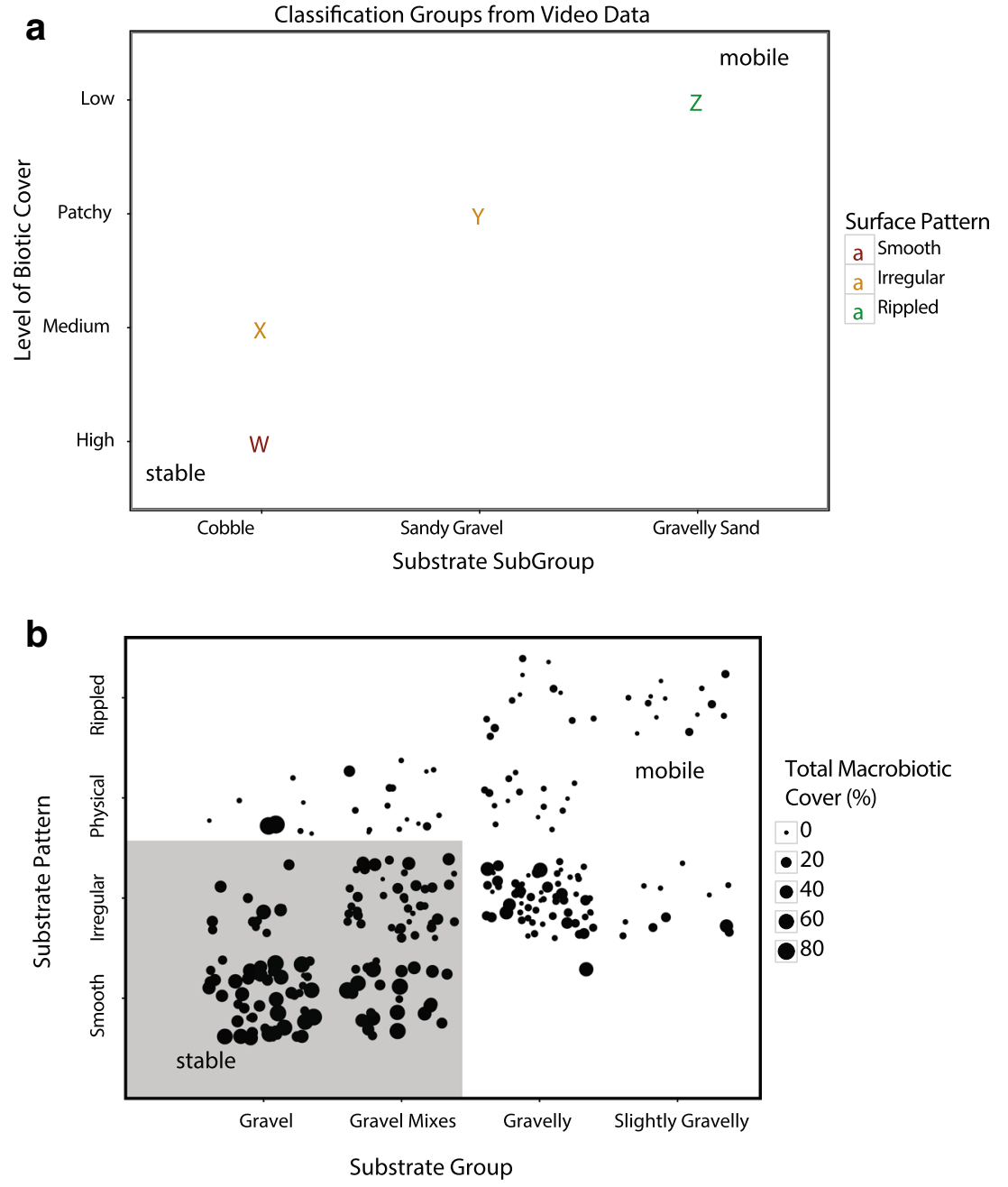
Fig. 3 Habitats displayed along a gradient of physical habitat stability/mobility (video groups indicated at left): those considered more mobile are frequently influenced by physical forcing and less likely to provide high value habitat for biological resources and more likely to recovery quickly from the effects of anchoring activity

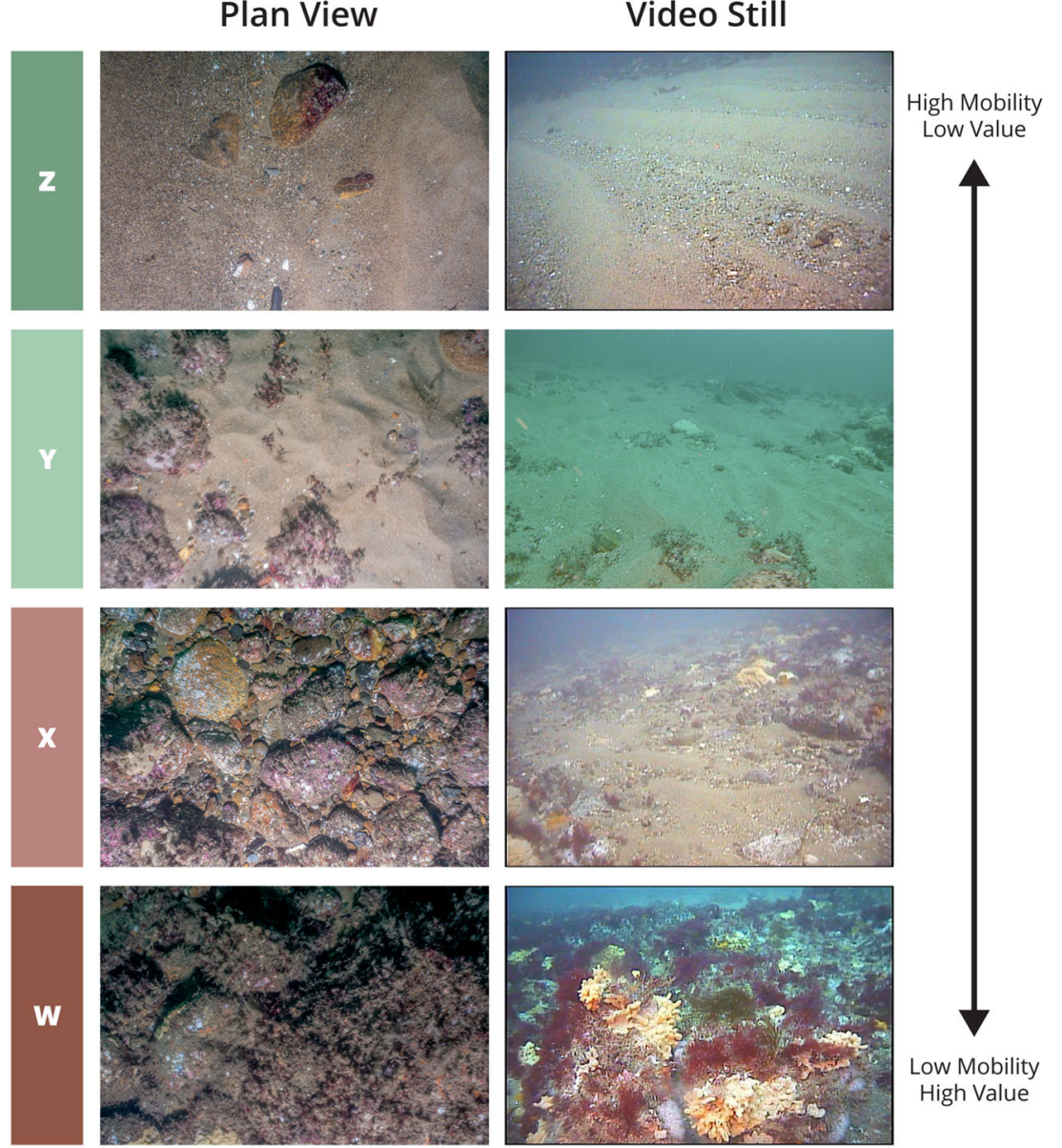

(V.10.1) and Golden Software Surfer (V.13) were used to create bathymetry and bathymetric relief maps.

To characterize habitats from video and PV imagery, we used and modified the national marine habitat classification standard, the Coastal and Marine Ecological Classification Standard (CMECS) (Federal Geographic Data Committee [FGDC] 2012), recommended by BOEM and NOAA for offshore wind benthic habitat assessments (BOEM 2019, NOAA Habitat 2020) and identified by the Northeast Regional Ocean Council for use in marine spatial planning (Shumchenia et al. 2015). The Substrate and Biotic components of CMECS were the primary focus of this study. The Substrate Component is used to classify seafloor surface sediments, as well as biogenic and anthropogenic substrates; the Biotic Component is used to classify dominant biotic assemblages, often along with their primary physical associations. These components are both hierarchical in structure, can be applied across a variety of spatial and temporal scales, and together facilitate an understanding of relationships between physical and biological habitats across spatial scales. Annual sampling and classification of these components over a 5-year period using imagery has been recommended as a rapid assessment tool for assessing changes to benthic community structure at offshore wind installations
(Shumchenia 2011). For this study, we used the Substrate Component classifiers of Group and Subgroup and the Surface Pattern modifier, which describes patterns in surface sediments that indicate physical disturbance. We used the Biotic Component classifiers of Class, Subclass, Group, and Community, as well as Percent Cover, Co-occurring Element, and Associated Taxa modifiers. Each classifier aligns with specific BOEM Guidelines and NOAA Habitat Recommendations for benthic assessments to be included in Construction and Operation Plans (Table 1).

Video imagery was viewed using VLC media player software. Classification terms were recorded during viewing and captured for distinct segments of the seafloor. Separations between segments were identified as noticeable shifts in Substrate Group (overall prevalence of gravel, sand, and gravelly sand) and/or benthic biotic cover and composition. Classifications of the Substrate and Biotic components (Table 1) were completed for Summer 2015 video. Descriptive habitat groups developed during Summer 2015 analysis (Table 2) were used for classification of March and August 2016 video. The habitat groups were compiled from Substrate Subgroup, Surface Pattern, and estimated levels of biotic cover to distinguish between mobile areas with frequent 


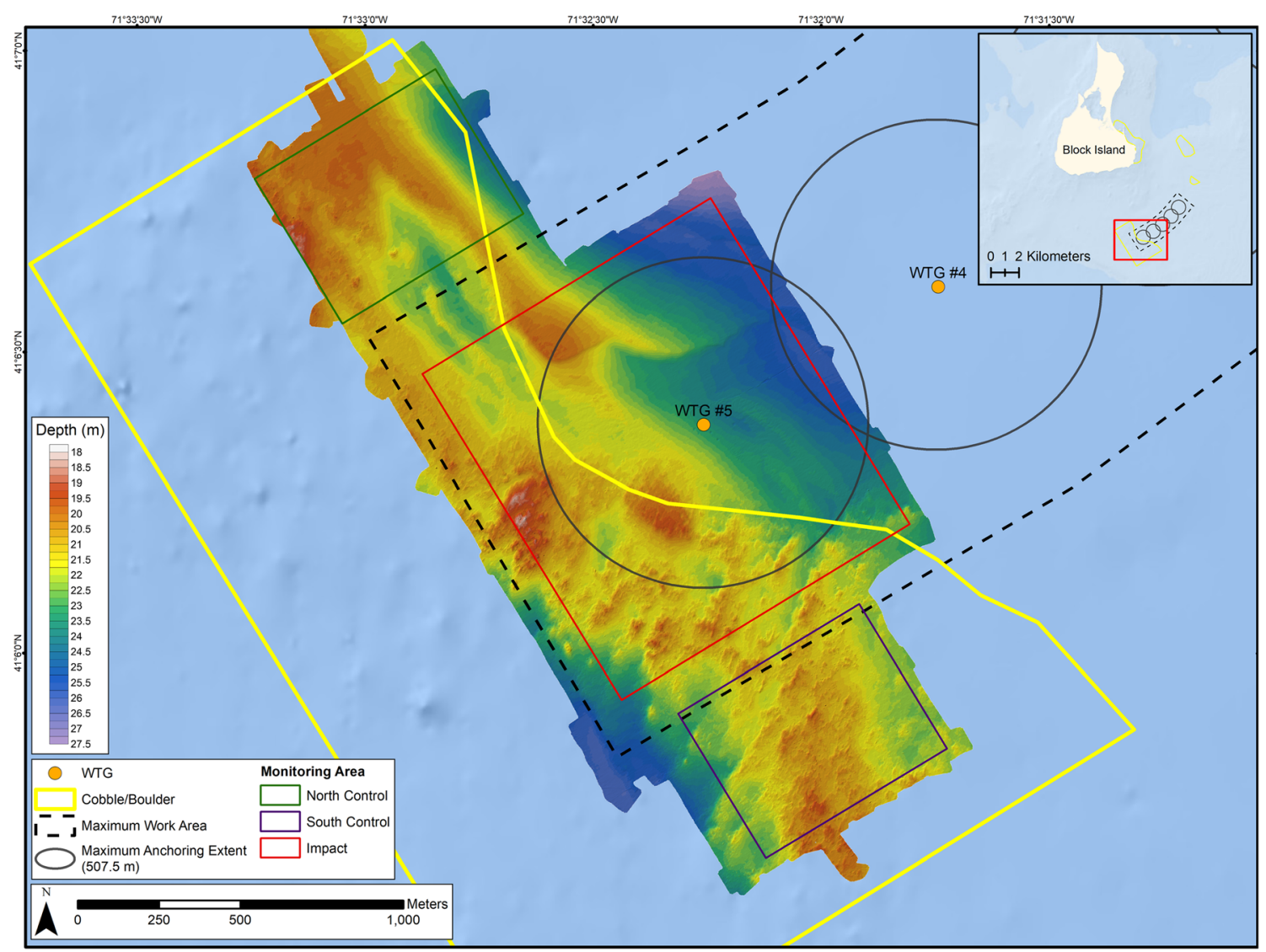

Fig. 4 Bathymetric data depicting seafloor topography in the study area

natural disturbance (e.g., ripples, gravel with few signs of epiflora/epifauna) and stable areas with less frequent natural disturbance (e.g., high biotic cover, cobble beds) (Fig. 2a). Habitat groups $\mathrm{W}$ and $\mathrm{X}$ represent more stable habitats. Group $\mathrm{Z}$ represents habitats that are more mobile and group $\mathrm{Y}$ represents a mid-point along this stable-to-mobile spectrum as these habitats contain patches of valuable habitat for biological resources within a matrix of more mobile physical habitats (Fig. 3).

Raw PV images were converted to high-resolution Photoshop Document (PSD) format files and analyzed using Adobe Photoshop ${ }^{\circledR}$ CC. Measurements were taken to calculate the field-of-view for all images; the mean field-of-view was $0.63 \mathrm{~m}^{2}$ (SD 0.69) in Summer 2015, 0.72 $\mathrm{m}^{2}$ (SD 0.16) in March 2016, and $0.83 \mathrm{~m}^{2}$ (SD 0.21) in August 2016. Quantitative measurements were made on Summer 2015 and March 2016 PV images to calculate the length of the largest sediment grain visible ( $>4 \mathrm{~mm}$, i.e., gravel), percent cover of primary and of co-occurring Biotic Groups, and total percent macrobiotic cover. Replicate results were summarized at the station level as station means for area-wide descriptions. Classifications of each image were completed on a percent cover basis for CMECS Substrate and Biotic components (Table 1). A physical habitat stability modifier was developed from Summer 2015 and March 2016 data to characterize each
PV image as either stable or mobile, using Substrate Group, Surface Pattern, correlated with total macrobiotic cover (Fig. 2b). Images that classified as Gravel or Gravel Mixes and Smooth or Irregular were considered stable habitats, whereas images that classified as Gravelly or Slightly Gravelly and Physical or Rippled or Gravel/Gravel Mixes and Physical were labeled mobile. Analysis of August 2016 PV images was streamlined - after categorized using the physical habitat stability modifier, Biotic Component classifications were completed for only those images that were categorized as "stable" as these represented the habitats of concern for impacts from anchoring activity. For these images, total percent macrobiotic cover was also measured.

\section{Results}

\section{Benthic Habitat Characterization}

Bathymetric data revealed a seafloor characterized by varied topographic relief with features oriented northwest to southeast. These patterns are consistent with a glacial history, with topographic highs representing moraines comprised of cobble/boulder ridges with low sediment availability (O'Hara and Oldale 1980), and with deeper sandy areas 
characterized by high sediment availability and frequent reshaping by physical forcing, e.g., storms, tides. Topographic highs were evident in the northwest corner of the survey area with a ridge line extending into the maximum anchoring extent boundary and in the area immediately southwest of the WTG. Most of the survey area located southwest and south of the WTG was characterized by mixed topography (Fig. 4). Seafloor habitats were also varied and patchy in distribution ranging from rippled, slightly gravelly sand supporting sparse biota to near continuous cobble/boulder fields supporting diverse and abundant life. In between these two ends of the spectrum were habitats of gravelly sand with scattered pebbles and cobbles with little macrobiotic cover, sandy gravel with low macrobiotic cover, and sandy gravel with a moderate cover of cobbles and macrobiota.

Measurements of the largest grain size visible in each PV image correlated well with the grain size gradient expressed in CMECS Substrate Groups. Larger sized gravels were found in images classified as Gravel or Gravel Mixes and smaller size gravels were found in images classified as Gravelly and Slightly Gravelly (Fig. 5a). Those PV stations with a Surface Pattern Modifier of Smooth generally overlapped with
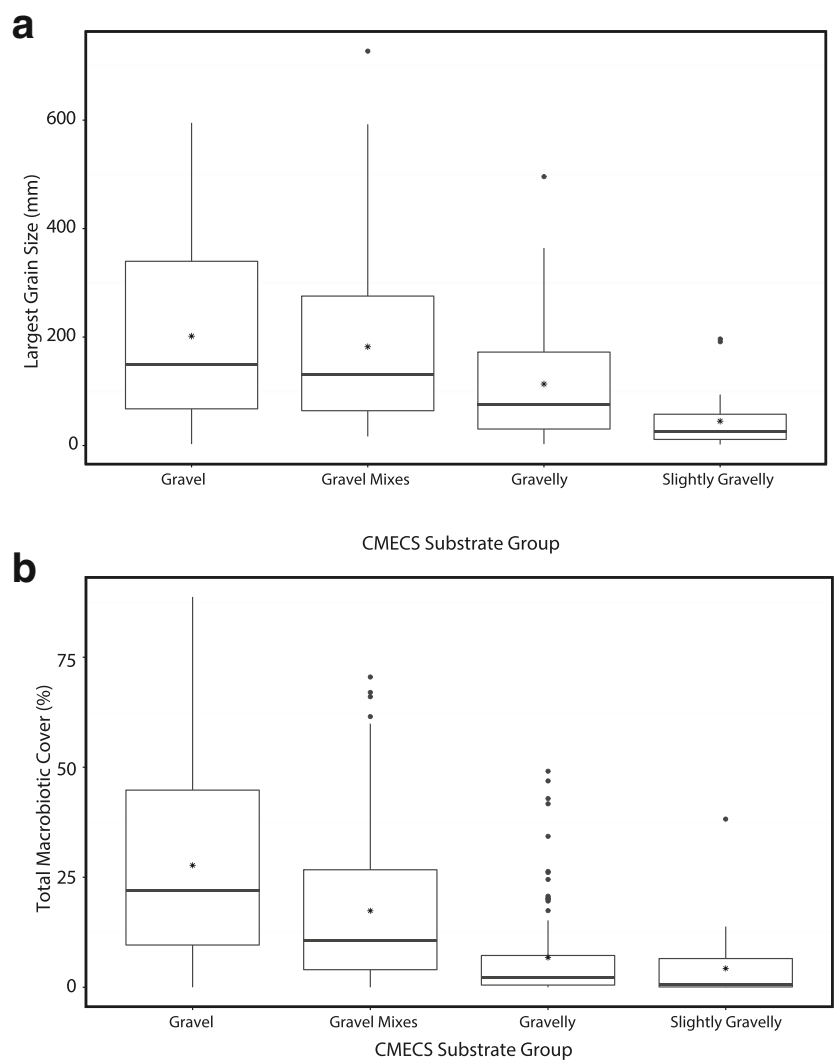

Fig. 5 Physical and biological habitat relationships in PV and video imagery: a boxplot showing distribution of largest gravel size $(\mathrm{mm})$ measured for each Substrate Group in PV replicate images in Summer 2015 and March 2016 and b boxplot showing distribution of total percent macrobiotic cover measured for each Substrate Group in PV replicate images in Summer 2015 and March 2016 topographic highs indicative of ridges and pavements and areas with variable topographic relief, whereas stations sampled in the deeper, sandier areas classified as Physical or Rippled. Stations classified as "Irregular" were found throughout the area (Fig. S1).

Dominant flora and fauna (by percent cover) were generally consistent across surveys, with predictable seasonal differences observed between the summer and winter (March) surveys, with more robust algal communities present in the summer (Table 3). Some differences were observed among surveys in observed presence of secondary dominant and mobile fauna (Table 3). Dominant flora were red algae, primarily Phyllophora spp.; dominant fauna were the colonial tunicate Didemnum vexillum and bryozoans, primarily Bugula spp. Additional taxa observed included crustose algae, sponges, sea stars, barnacles, anemones, moon snails, clams, tube worms, non-reef-building corals, and nudibranchs, as well as nudibranch and squid eggs (Table 3 ). Total macrobiotic cover correlated with gravel composition, with a decreasing trend in biotic cover from Gravel to Gravel Mixes to Gravelly and Slightly Gravelly (Fig. 5b).

Overall spatial patterns in physical habitat stability were consistent between surveys with stable habitats clustered along topographic highs and ridges and mobile habitats predominantly found in deeper, sandy areas. Habitats identified as stable represent those considered to be complex, high value hard bottom habitats (cobbles/boulders, high biotic cover, Fig. 3 ), and the distribution of biotic cover across CMECS Substrate Groups support this conclusion and the use of Substrate Groups as a biologically meaningful predictor within moraine habitats (Fig. 5b). Areas of mixed topography contained both stable and mobile habitats. Habitats along video transects were also more variable in areas where seafloor topography was highly varied, such as immediately to the southwest of the maximum anchoring extent and in much of the southern control area. As the habitat group that captured patchy habitat mosaics, group $\mathrm{Y}$ was observed throughout the survey area coincident with multiple types of seafloor topography. Reference areas to the north and south were confirmed as representative of habitats found in the area where anchoring occurred (Fig. 6).

\section{Detecting Construction Impacts}

Anchoring activity was evident in bathymetric data and video imagery, presenting as a distinct pattern similar to a furrow in a field (Fig. 7, Fig. S2). The anchor furrows appeared as parallel linear features in the MBES data (Fig. 7). Video imagery revealed furrow edges as distinct lines of cobbles and boulders raised above the sand and dragged into linear arrays separated by an area of rippled gravelly sand (Fig. 7, Fig. S2). Anchor furrows were detected in areas of mixed topography and moderate value habitat ( $\mathrm{Y}$ and some $\mathrm{X}$ video habitat groups) near the boundary of the Cobble/Boulder Area outlined in 
Table 3 Taxa observed with the presence and absence noted all three surveys

\begin{tabular}{|c|c|c|c|c|c|}
\hline Taxa-common type & $\begin{array}{l}\text { Taxa-lowest taxonomic } \\
\text { identification possible }\end{array}$ & Presence level & Summer 2015 & March 2016 & August 2016 \\
\hline \multicolumn{6}{|l|}{ Algae } \\
\hline Red algae & Phyllophora spp. & Primary, secondary in Aug 2016 & $\mathrm{Y}$ & $\mathrm{Y}$ & $\mathrm{Y}$ \\
\hline Turf algae & Turf algae & Secondary primary in Aug 2016 & $\mathrm{Y}$ & $\mathrm{N}$ & $\mathrm{Y}$ \\
\hline Coralline/crustose algae & Coralline/crustose algae & Secondary & $\mathrm{Y}$ & $\mathrm{Y}$ & $\mathrm{Y}$ \\
\hline Green algae & Green algae & Secondary & $\mathrm{Y}$ & $\mathrm{N}$ & $\mathrm{N}$ \\
\hline Brown algae & Saccharina latissima & Secondary & $\mathrm{N}$ & $\mathrm{N}$ & $\mathrm{Y}$ \\
\hline Anemones & Anemone species (various) & Associated & $\mathrm{Y}$ & $\mathrm{Y}$ & Y \\
\hline \multicolumn{6}{|l|}{ Arthropods } \\
\hline Barnacles & Barnacles & Associated & $\mathrm{Y}$ & $\mathrm{Y}$ & Y \\
\hline Crabs & Cancer spp. & Associated & $\mathrm{Y}$ & $\mathrm{Y}$ & $\mathrm{N}$ \\
\hline \multicolumn{6}{|l|}{ Bivalves } \\
\hline Chesnut clam & Astarte castanea & Associated & $\mathrm{Y}$ & $\mathrm{Y}$ & Y \\
\hline Tellin clams & Tellinidae & Associated & $\mathrm{Y}$ & $\mathrm{N}$ & $\mathrm{N}$ \\
\hline \multicolumn{6}{|l|}{ Bryozoans } \\
\hline & Bugula spp. & Primary & $\mathrm{Y}$ & $\mathrm{Y}$ & $\mathrm{Y}$ \\
\hline \multicolumn{6}{|l|}{ Coral } \\
\hline Northern star coral & Astrangia poculata & Associated; Sensitive & $\mathrm{Y}$ & $\mathrm{Y}$ & $\mathrm{Y}$ \\
\hline \multicolumn{6}{|l|}{ Gastropods } \\
\hline Sea snail & Bittium spp. & Associated & $\mathrm{Y}$ & $\mathrm{N}$ & $\mathrm{N}$ \\
\hline Moon snail & Naticidae & Associated & $\mathrm{Y}$ & $\mathrm{Y}$ & $\mathrm{N}$ \\
\hline Slipper shell & Crepidula spp. & Associated & $\mathrm{Y}$ & $\mathrm{N}$ & $\mathrm{N}$ \\
\hline \multicolumn{6}{|l|}{ Nudibranch and eggs } \\
\hline & Nudibranch and eggs & Associated, Sensitive & $\mathrm{N}$ & $\mathrm{Y}$ & $\mathrm{N}$ \\
\hline \multicolumn{6}{|l|}{ Sea stars } \\
\hline Common sea star & Asterias spp. & Associated & $\mathrm{Y}$ & $\mathrm{Y}$ & $\mathrm{N}$ \\
\hline Blood star & Henricia spp. & Associated & $\mathrm{N}$ & $\mathrm{Y}$ & $\mathrm{Y}$ \\
\hline \multicolumn{6}{|l|}{ Sponges } \\
\hline Aggregated nipple sponge & Polymastia spp. & Associated & $\mathrm{Y}$ & $\mathrm{Y}$ & $\mathrm{Y}$ \\
\hline Red boring sponge & Cliona celata & Secondary & $\mathrm{N}$ & $\mathrm{Y}$ & $\mathrm{N}$ \\
\hline Red encrusting sponge & Microciona spp. & Secondary & $\mathrm{Y}$ & $\mathrm{Y}$ & $\mathrm{Y}$ \\
\hline \multicolumn{6}{|l|}{ Squid eggs } \\
\hline Longfin squid eggs & Doryteuthis (Amerigo) pealeii & Associated; sensitive & $\mathrm{Y}$ & $\mathrm{N}$ & $\mathrm{N}$ \\
\hline Tube worms & Tube worms & Secondary & $\mathrm{N}$ & $\mathrm{Y}$ & $\mathrm{N}$ \\
\hline \multicolumn{6}{|l|}{ Tunicate } \\
\hline Colonial tunicate & Didemnum vexillum & Primary & $\mathrm{Y}$ & $\mathrm{Y}$ & $\mathrm{Y}$ \\
\hline
\end{tabular}

Deepwater Wind's Anchor Plan (Fig. 8a). Five anchor furrows were detected ranging in length from 32 to $145 \mathrm{~m}$, all 3-5 $\mathrm{m}$ across. The area of seafloor altered by these anchor furrows was between approximately 1287 and $2145 \mathrm{~m}^{2}$.

In March 2016, these cobbles and boulders had zero to trace biotic cover and the furrow middles were predominantly rippled gravelly sand with few cobbles or boulders (Fig. 8b). All five furrows were again observed in the bathymetric and video data collected in August 2016 (Fig. 9a). Their physical form was largely unchanged, but key differences in biotic cover were observed. In contrast to furrow edges that were mostly bare in March 2016, moderate biotic cover (mostly Didemnum vexillum) was observed in the August 2016 imagery (Fig. 9b). In August 2016, the furrow edges were similar to stable ( $\mathrm{W}$ and $\mathrm{X}$ ) habitats and the middles of the furrow remained gravelly sand $(Z)$, but the pronounced ripples 
Fig. 6 Spatial distribution of habitats represented in terms of physical habitat stability/mobility from $\mathbf{a}$ PV and $\mathbf{b}$ video imagery collected in Summer 2015 and March 2016
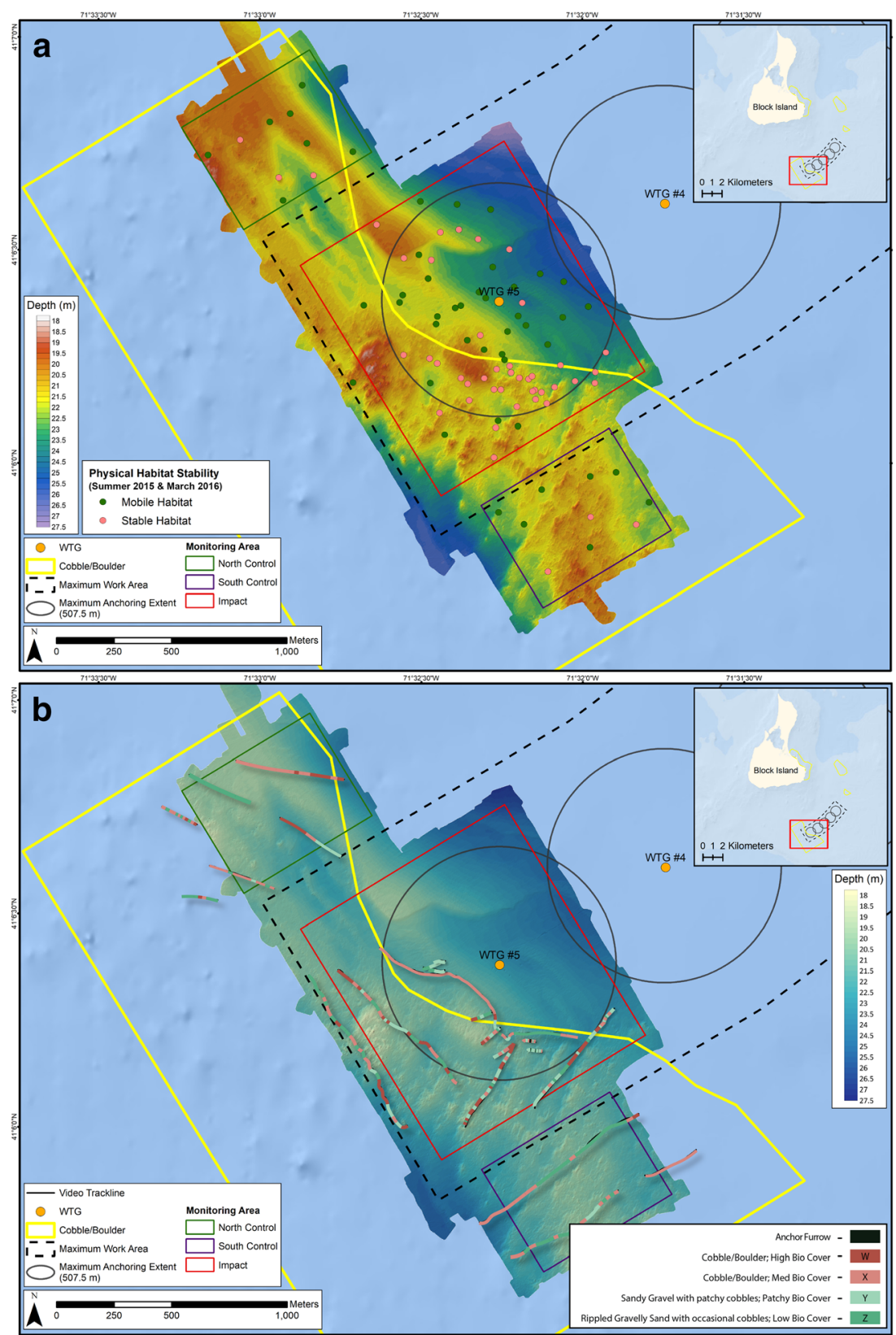

observed in March were no longer present and Didemnum vexillum were observed on small cobbles. Although several PV images mapped directly to furrow locations, we observed no definitive evidence of disturbance from anchoring activity in these images.

\section{Discussion}

Moraine habitats located adjacent to the BIWF served as a testing ground for benthic characterization and impact assessment methodologies in these diverse and complex areas. Using a multi-modal approach combining high-resolution
MBES data and imagery from towed video and PV cameras allowed us to assemble detailed baseline data on abiotic and biotic habitat features to detect discrete anchoring disturbance features and to present this information to state and federal agencies in accessible and meaningful ways. MBES data provided seascape scale data on seafloor topography that were instrumental in guiding PV and video imagery sampling. Video imagery provided a view at the geoform scale and allowed detection of habitat patterns and PV imagery provided the means to quantify physical and biological characteristics of the seafloor at a granular scale and identify specific taxa present. The use of high-resolution acoustic data in combination with visual imagery has since been highlighted as the 
Fig. 7 Anchor furrows detected in bathymetric data and video imagery

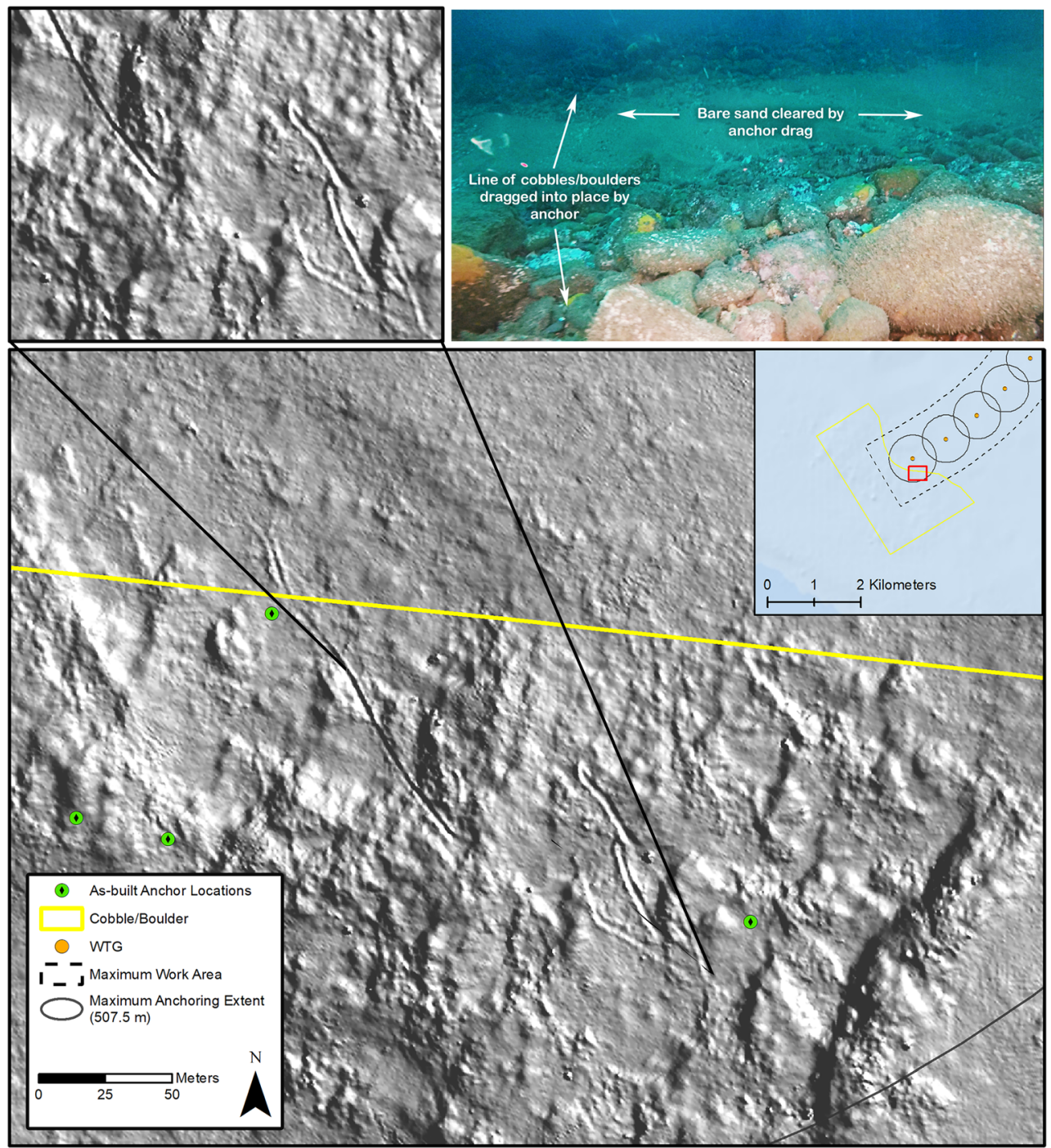

recommended methodology for assessing seafloor habitats for U.S. offshore wind development, particularly in areas of complex habitats such as moraines (NOAA Habitat 2020).

Detailed baseline knowledge of benthic habitat distribution and characteristics is essential for assessing and monitoring construction effects. Additionally, accurate benthic habitat maps are critically important for successful micro-siting of turbines and cables to avoid sensitive habitats in cases where construction in these habitats cannot be completely avoided (Pearce et al. 2014; NOAA 2019). Continued developer-led surveys to support offshore wind development represent an ongoing opportunity to improve baseline data about offshore moraine habitats. The baseline data we collected confirm and provide additional detail on the glacial ridge and swale setting on the eastern continental shelf. Observed differences in associated taxa across our surveys (Table 3 ) may be due to life history differences, reduced visibility due to algal cover in summer, and to sampling chance.

\section{Assessing Construction Impacts}

A combination of high-resolution MBES and imagery data was essential for detecting construction impacts to the seafloor. Had the MBES data not been available, we would have only had as-built drawings provided by construction engineers as a guide for imagery surveys. These were not well correlated with anchor furrows and appeared to mark the location of anchor entry in the water column rather than contact with the seafloor (Fig. 7a). Given these limitations and the discrete scale of the anchor furrows, it would have been nearly impossible to position video transects to detect anchor disturbance features without high-resolution MBES data. Definitive evidence of disturbance from anchors was not found in PV images. PV imagery was not an appropriate tool for identifying these disturbance features because of the discrete scale and pattern of the anchor furrows and the $<1 \mathrm{~m}^{2}$ scale of each PV image. For example, had the PV frame landed in the 
Fig. 8 Habitats disturbed by anchoring activity, a habitat distribution and evidence of anchor furrows (all transects from March 2016 survey except as labeled), $\mathbf{b}$ anchor furrow in March 2016 showing nearly bare cobbles and boulders at the edges, and $\mathbf{c}$ conceptual plot of disturbance trajectory a

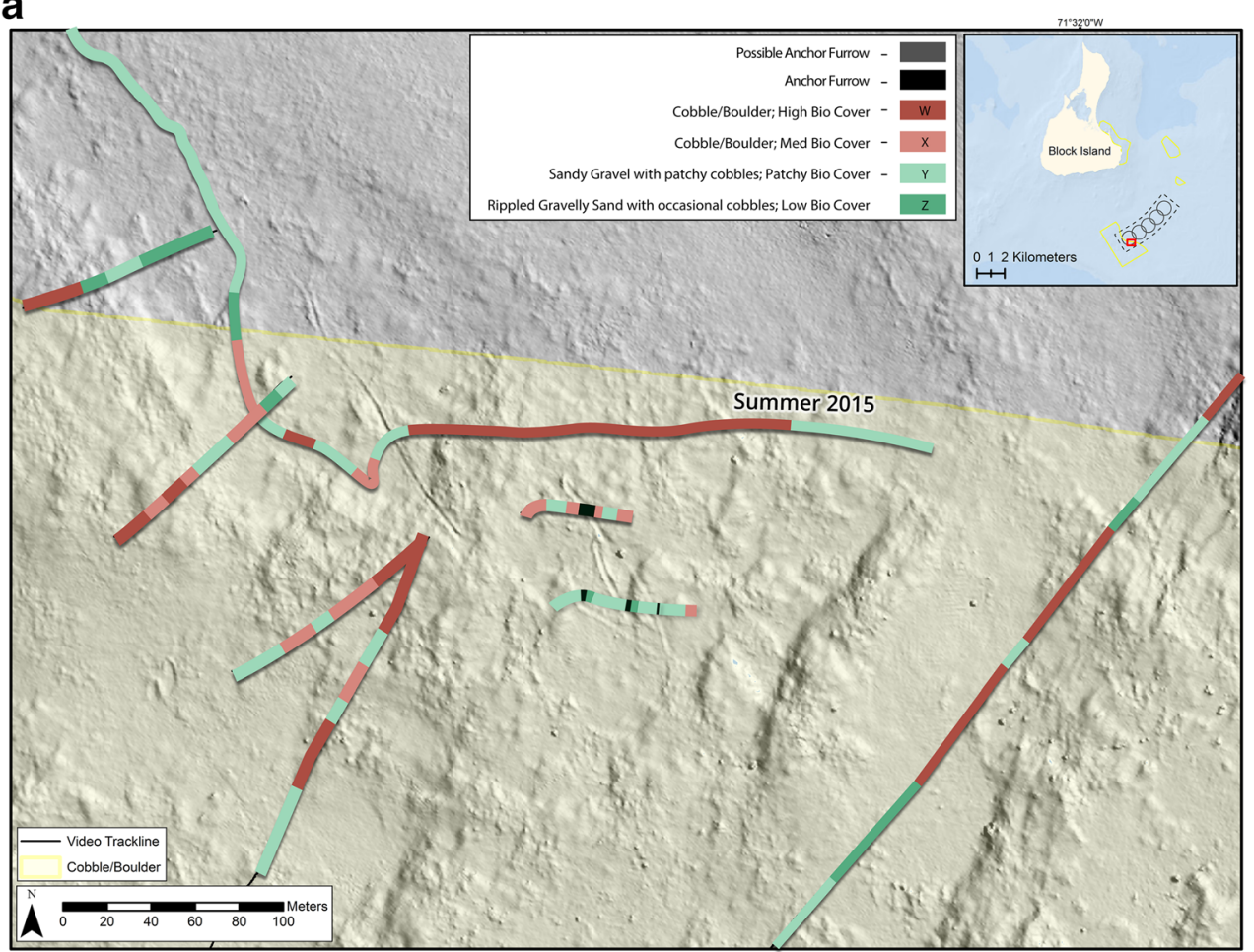

b

C

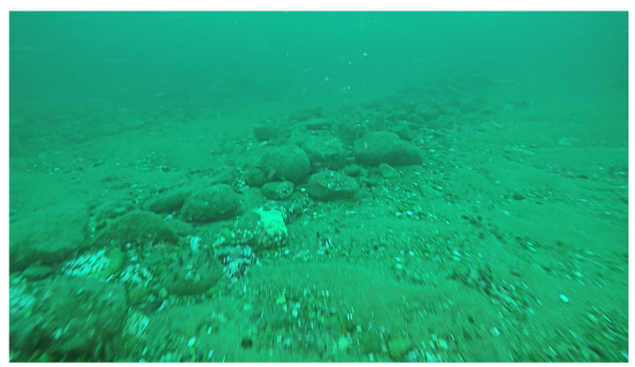

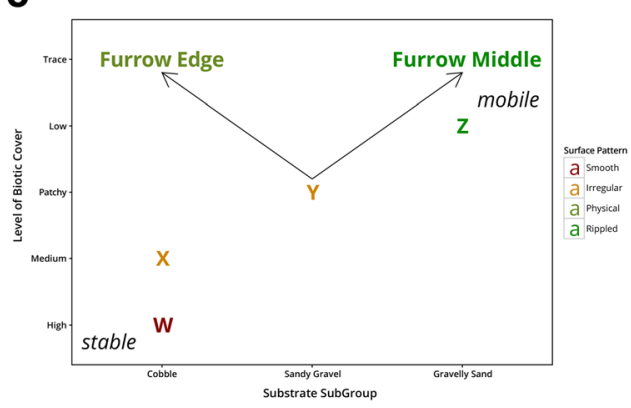

middle of an anchor furrow (3-5 m wide), it would not have been possible to affirmatively distinguish the seafloor there from a naturally occurring patch of gravelly sand. However, PV imagery was instrumental in evaluating physical and biological habitat relationships and provided a valuable means to visually calibrate taxa captured in video imagery and to assess species composition (Table 3).

Anchor furrows were detected in MBES and video data in moderate value mixed sandy gravel with patches of cobbles and boulders (video habitat group Y) (Fig. 8). More anchor locations were recorded by construction engineers than were identified as furrows in our surveys (Fig. 7a), although some of these markers may indicate anchor drops that were not successful in holding position. It is possible that other habitats were also disturbed by anchoring and related features were not detectable using our methods. For example, in rippled gravelly areas, storms and tides may have erased anchor furrows from the seafloor between completion of construction and the March 2016 survey. In cobble/boulder fields, anchors could have rearranged the substrate matrix by turning over individual cobbles/boulders; however, the acoustic signature detected by the MBES would likely have been the same as that of undisturbed cobbles/boulders. Despite extensive data collection efforts, we found no visual evidence of disturbance to these high value continuous hard bottom habitats. However, had undetected anchoring disturbance occurred in these habitats, it is likely recolonization would have occurred in a similar time frame as where anchor furrows were detected, given similar proximity to robust populations of attached fauna.

The action of the anchor was a disturbance to the seafloor that resulted in a shift away from a patchy habitat in equilibrium $(\mathrm{Y})$ to two linear arrays of cobbles and boulders separated by a 3-5 m swath of gravelly sand (Fig. $8 \mathrm{c}$ ). Biotic cover of the furrow edges increased from trace to moderate between March and August 2016 indicating relatively fast recolonization, primarily by the colonial tunicate Didemnum vexillum. This species was prevalent across all three surveys and is a non-native species that has been found to be dominant in 
Fig. 9 Anchor furrows 1 year after construction in August 2016, a habitat distribution and continued presence of anchor furrows, $\mathbf{b}$ anchor furrow in August 2016 showing cobbles and boulders at the edges recolonized by tunicates, and $\mathbf{c}$ conceptual plot of recovery trajectory

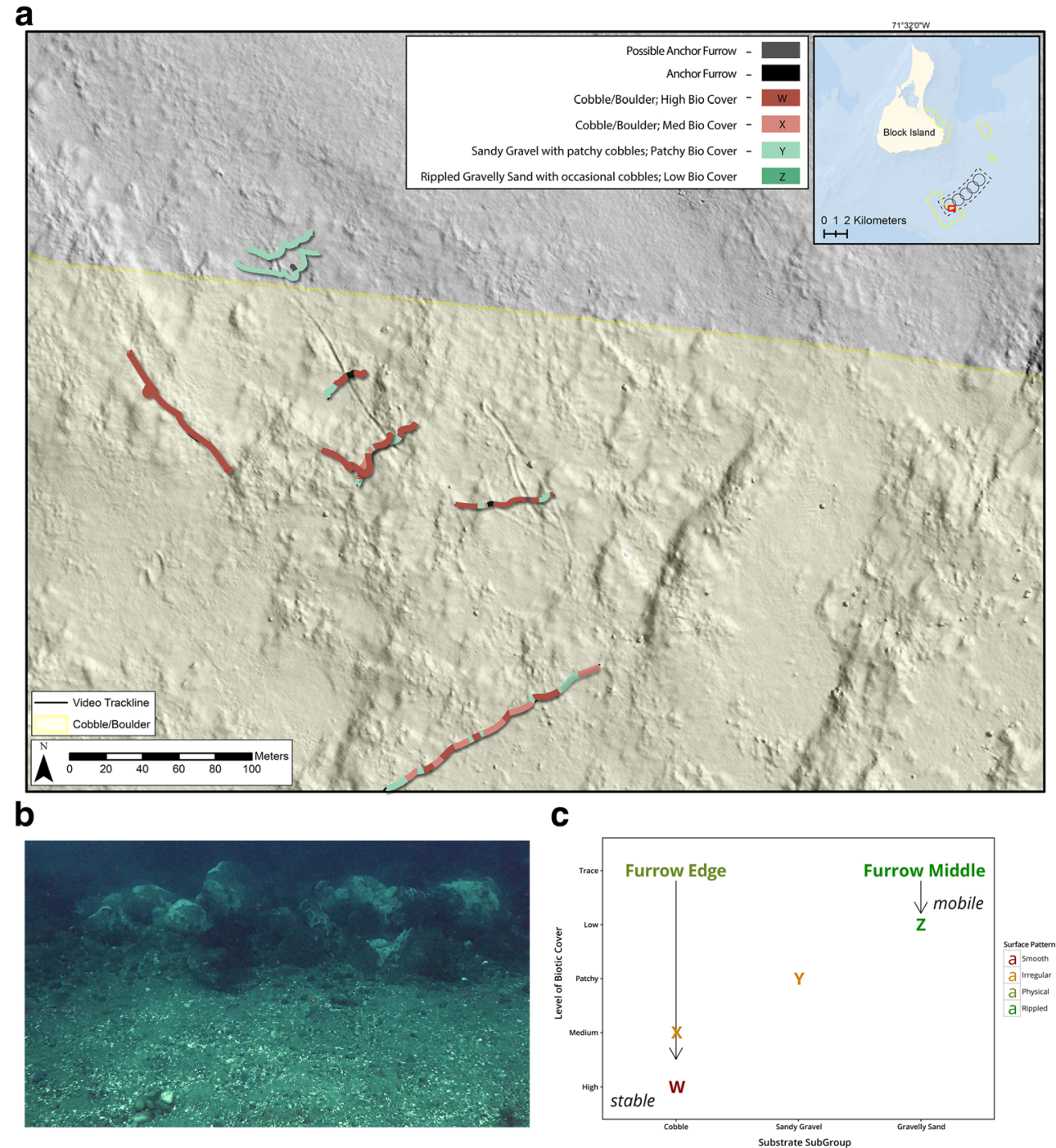

many nearshore subtidal communities along the U.S. northeastern coast (Bullard et al. 2007a), including nearby Narragansett Bay, RI (Auker 2019). On Georges Bank, an important New England fishing ground, very high cover of Didemnum vexillum has significantly altered benthic communities, with its presence associated with increased abundance of polychaetes and crabs and high community diversity (Smith et al. 2011). Within the moraine habitat adjacent to the BIWF, Didemnum vexillum was observed as part of a diverse attached faunal community, in contrast to the encrusting mats observed to overgrow pebble and cobble pavements and associated taxa on Georges Bank (Valentine et al. 2007). This colonial tunicate is a successful colonizer (Bullard et al. 2007a) in part because it can reproduce asexually and sexually and produce fragments to spread quickly beyond its initial settlement site (Bullard et al. 2007b). It is also possible that the relatively quick recolonization $(<1$ year) was aided by stable habitat patches with robust populations of these taxa in close proximity to anchor furrows. While our surveys indicated that Didemnum vexillum was the first dominant colonizer of the furrow edges, without additional data we can only hypothesize that these cobbles and boulders will eventually host a diversity of sessile and mobile taxa similar to nearby stable complex habitats (Fig. 9c). Although the biotic communities of the anchor furrows may come to resemble nearby habitats, the physical alteration to the seafloor will remain; indeed, anchor marks are considered important anthropogenic attributes to consider when classifying and mapping the seafloor (Kenny et al. 2003).

Given how critical cobble habitat is to juvenile American lobsters (Wahle and Steneck 1991), consideration of the potential effects of anchoring activity on this economically important species is warranted. Juvenile lobsters have been shown to move outside of shelter locations more often in continuous cobble than in patchy cobble habitats (Hovel and Wahle 2010), suggesting that continuous and near continuous cobble beds (video habitat groups $\mathrm{W}$ and $\mathrm{X}$ ) are of higher value to the American lobster. Therefore, the restructuring of patchy cobble 
boulder habitat $(\mathrm{Y})$ to linear arrays of cobbles and boulders may indicate a potential small-scale benefit to juvenile lobsters as it is possible these could serve as high value continuous habitat for juvenile lobsters. The furrow edges may also provide more complexity and opportunity for refuge than the surrounding mixed habitat. This hypothesis is supported by research showing that predation rates on juvenile lobsters in Rhode Island are highest at patch edges and decrease toward the center of cobble patches (Selgrath et al. 2007). Additionally, it is unlikely construction anchoring left juvenile lobsters without available habitat as their daily home ranges have been shown to be 27.4 to $111.6 \mathrm{~m}^{2}$ on average (Morse and Rochette 2016) and the anchor furrows were $5 \mathrm{~m}$ across at the widest point.

\section{Lessons for Future Application}

At this time, ours is the only available study of U.S. offshore wind post-construction benthic monitoring in moraine habitats. Given the discrete scale and number of anchor furrows detected, conclusions regarding moraine habitat recovery from offshore wind construction drawn from this study should be used as hypotheses to be tested at more extensive developments planned within moraine habitats, where extensive preconstruction surveys and benthic habitat mapping efforts are underway (DWSF 2020; DWW REV I 2020). Further, additional activities that will permanently or temporarily disturb the seafloor such as placement of scour pads around WTG foundations and boulder relocation to prepare the seafloor for WTG and cable installation were not required at the BIWF, but are planned at other offshore wind development sites (DWSF 2020; DWW REV I 2020). Boulder relocation can have a similar effect to pulling an anchor across the seafloor (DNVGL 2016) and the anchor furrows detected at the BIWF may provide useful analogs for boulders relocated during construction for these projects.

The BIWF was a springboard for the offshore wind industry in the U.S., and benthic assessment techniques developed during this study have served as a launching point for assessments undertaken at a number of offshore wind leases on the U.S. Atlantic coast, particularly in New England where moraine habitats are found (DWSF 2020; DWW REV I 2020). Our work at the BIWF demonstrates the advantages of a multi-modal methodology integrating MBES and highresolution imagery for characterizing hard bottom moraine habitats to conduct impact assessments; methods now recommended by federal agencies (NOAA Habitat 2020). The manner in which benthic assessment results are presented to state and federal agencies is also critical to advancing the environmental review and permitting process. We modified CMECS to present our results in terms of biotic habitat value and predicted vulnerability to disturbance (Fig. 3). Specifically, the physical habitat stability modifier provided a single variable for mapping habitat distributions (Fig. 6) that was directly linked to CMECS classifiers and to representative images (Fig. 3). CMECS continues to be the preferred methodology for classifying seafloor substrates for offshore wind benthic assessments and EFH consultations (BOEM 2019; NOAA Habitat 2020) and serves as the foundation from which benthic habitats are currently being mapped and assessed in the U.S. (DWSF 2020; DWW REV I 2020; SJOE 2020).

Acknowledgments Deepwater Wind LLC contracted INSPIRE Environmental to conduct this study and we are grateful for their support and dedication to protection of ocean resources, with specific thanks to Aileen Kenney, John O'Keefe, and Jeff Grybowski. Many thanks to Ben Taylor and Steve Sabo for creation of maps and visualization products. Thanks to Jimmy Flynn for assistance with image analysis and video annotation, to Chris Wright for collecting and processing multibeam data, and to Chip Ryther for collecting towed video data. Thank you to Lorraine Brown Read for support in designing a statistically valid survey. This work would not have been possible without the assistance of the field collection teams from INSPIRE Environmental and CR Environmental and of the crew of the $R / V$ Jamie Hanna. Thank you to anonymous reviewers whose comments led to improvements in this manuscript.

Open Access This article is licensed under a Creative Commons Attribution 4.0 International License, which permits use, sharing, adaptation, distribution and reproduction in any medium or format, as long as you give appropriate credit to the original author(s) and the source, provide a link to the Creative Commons licence, and indicate if changes were made. The images or other third party material in this article are included in the article's Creative Commons licence, unless indicated otherwise in a credit line to the material. If material is not included in the article's Creative Commons licence and your intended use is not permitted by statutory regulation or exceeds the permitted use, you will need to obtain permission directly from the copyright holder. To view a copy of this licence, visit http://creativecommons.org/licenses/by/4.0/.

\section{References}

Auker, L.A. 2019. A decade of invasion: changes in the distribution of Didemnum vexillum Kott, 2002 in Narragansett Bay, Rhode Island, USA, between 2005 and 2015. BioInvasions Record 8 (2): 230-241.

Barrie, J.V., B.J. Todd, A.D. Heap, H.G. Greene, C. Cotterill, H. Stewart, and B. Pearce. 2014. Geoscience and habitat mapping for marine renewable energy - introduction to the special issue. Continental Shelf Research 83: 1-2.

Bilgili, M., A. Yasar, and E. Simsek. 2011. Offshore wind power development in Europe and its comparison with onshore counterpart. Renewable and Sustainable Energy Reviews 12: 905-915.

Bishop, M.J., M. Mayer-Pinto, L. Airoldi, L.B. Firth, R.L. Morris, L.H.L. Loke, S.J. Hawkins, L.A. Naylor, and R.A. Coleman. 2017. Effects of ocean sprawl on ecological connectivity: impacts and solutions. Journal of Experimental Marine Biology and Ecology 492: 7-30.

Bullard, S.G., G. Lambert, M.R. Carman, J. Brynes, R.B. Whitlatch, G. Ruiz, R.J. Miller, L. Harris, P.C. Valentine, J.S. Collie, J. Pederson, D.C. McNaught, A.N. Cohen, R.G. Asch, J. Dijkstra, and K. Heinonen. 2007a. The colonial ascidian Didemnum sp. A: current distribution, basic biology and potential threat to marine communities of the northeast and west coasts of North America. Journal of Experimental Marine Biology and Ecology 342 (1): 99-108. 
Bullard, S.G., B. Sedlack, J.F. Reinhardt, C. Litty, K. Gareau, and R.B. Whitlatch. 2007b. Fragmentation of colonial ascidians: differences in reattachment capability among species. Journal of Experimental Marine Biology and Ecology 342 (1): 166-168.

Bureau of Ocean Energy Management (BOEM). 2019. Guidelines for providing benthic habitat survey information for renewable energy development on the Atlantic Outer Continental Shelf, Pursuant to 30 CFR Part 585. U.S. Dept. of the Interior, Bureau of Ocean Energy Management, Office of Renewable Energy Programs, Herndon, VA. https://www.boem.gov/sites/default/files/renewable-energyprogram/Regulatory-Information/BOEM-Renewable-BenthicHabitat-Guidelines.pdf. Accessed 27 April 2020.

Carey, D.A., D.F. Doolittle, and K. Smith. 2019. Forward scouting: use of sediment profile imagery in conjunction with multibeam echosounder mapping for offshore wind cable routes and site characterization. Proceedings of the Offshore Technology Conference. Manuscript OTC-29220-MS.

Clark, D.S., and J.M. Green. 1990. Activity and movement patterns of juvenile Atlantic cod, Gadus morhua, in Conception Bay, Newfoundland, as determined by sonic telemetry. Canadian Journal of Zoology 68 (7): 1434-1442.

Costanza, R., R. d'Arge, R. de Groot, S. Farber, M. Grasso, B. Hannon, K. Limburg, S. Naeem, R.V. O’Neill, J. Paruelo, R.G. Raskin, P. Sutton, and M. van den Belt. 1997. The value of the world's ecosystem services and natural capital. Nature 387 (6630): 253-260.

Dannheim, J., L. Bergström, S.N.R. Birchenough, R. Brzana, A.R. Boon, J.W.P. Coolen, J. Dauvin, I. De Mesel, J. Derweduwen, A.B. Gill, Z.L. Hutchison, A.C. Jackson, U. Janas, G. Martin, A. Raoux, J. Reubens, L. Rostin, J. Vanaverbeke, T.A. Wilding, D. Wilhelmsson, and S. Degraer. 2019. Benthic effects of offshore renewables: identification of knowledge gaps and urgently needed research. ICES Journal of Marine Science 77: 1092-1108.

Deepwater Wind South Fork. 2020. Construction and operations plan, south fork wind farm. Prepared by Jacobs Engineering Group Inc., Providence, RI. Submitted to the Bureau of Ocean Energy Management, Sterling, VA. Revision 3. February 2020.

Diaz, R.J., M. Solan, and R.M. Valente. 2004. A review of approaches for classifying benthic habitats and evaluating habitat quality. Journal of Environmental Management 73 (3): 165-181.

DNVGL. 2016. Recommended practice: subsea power cables in shallow water. DNVGL-RP-0360 Edition March 2016. http://rules.dnvgl. com/docs/pdf/dnvgl/RP/2016-03/DNVGL-RP-0360.pdf. Accessed 3 May 2019.

DWW Rev I, LLC. 2020. Construction and operations plan, revolution wind farm. Prepared by VHB, Providence, RI. Submitted to the Bureau of Ocean Energy Management, Sterling, VA. March 2020.

Federal Geographic Data Committee (FGDC). 2012. FGDC-STD-0182012. Coastal and marine ecological classification standard. Reston, VA. https://www.fgdc.gov/standards/projects/cmecs-folder/ CMECS Version 06-2012 FINAL.pdf. Accessed 23 January 2019.

Firth, L.B., A.M. Knights, D. Bridger, A.J. Evans, N. Mieszkowska, P.J. Moore, N.E. O'Connor, E.V. Sheehan, R.C. Thompson, and S.J. Hawkins. 2016. Ocean sprawl: challenges and opportunities for biodiversity management in a changing world. Oceanography and Marine Biology: An Annual Review 54: 193-269.

Global Wind Energy Council (GWEC). 2019. Global wind report 2018. Brussels, Belgium. https://gwec.net/global-wind-report-2018/. Accessed 17 April 2019.

Gotceitas, V., and J.A. Brown. 1993. Substrate selection by juvenile Atlantic cod (Gadus morhua): effects of predation risk. Oecologia 93 (1): 31-37.

Griswold, C.A., and J. Prezioso. 1981. In-situ observations on reproductive behavior of the long- finned squid, Loligo pealei. Fishery Bulletin 78: 945-947.
Heery, E.C., M.J. Bishop, L.P. Critchley, A.B. Bugnot, L. Airoldi, M. Mayer-Pinto, E.V. Sheehan, R.A. Coleman, L.H.L. Loke, E.J. Johnston, V. Komyakova, R.L. Morris, E.M.A. Strain, L.A. Naylor, and K.A. Dafforn. 2017. Identifying the consequences of ocean sprawl for sedimentary habitats. Journal of Marine Experimental Marine Biology and Ecology 492: 31-48.

Hovel, K.A., and R.A. Wahle. 2010. Effects of habitat patchiness on American lobster movement across a gradient of predation risk and shelter competition. Ecology 91 (7): 1993-2002.

Kenny, A.J., I. Cato, M. Desprez, G. Fader, R.T.E. Schuttenhelm, and J. Side. 2003. An overview of seabed-mapping technologies in the context of marine habitat classification. ICES Journal of Marine Science. 60 (2): 411-418.

LaFrance, M., J.W. King, B.A. Oakley, and S. Pratt. 2014. A comparison of top-down and bottom-up approaches to benthic habitat mapping to inform offshore wind energy development. Continental Shelf Research 83: 24-44.

Lindeboom, H., S. Degraer, J. Dannheim, A.B. Gill, and D. Wilhelmsson. 2015. Offshore wind park monitoring programmes, lessons learned, and recommendations for the future. Hydrobiologia 756 (1): 169 180.

Liquete, C., C. Piroddi, E.G. Drakou, L. Gurney, S. Katsanevakis, A. Charef, and B. Egoh. 2013. Current status and future prospects for the assessment of marine and coastal ecosystem services: a systematic review. PLoS One 8 (7): e67737.

McCann, J. 2012. Developing environmental monitoring protocols and modeling tools to support ocean renewable energy and stewardship. US Dept. of the Interior, Bureau of Ocean Energy Management, Office of Renewable Energy Programs, Herndon, VA. OCS Study BOEM 2012-082. https://www.boem.gov/ESPIS/5/5208.pdf. Accessed 23 January 2019.

Morse, B., and R. Rochette. 2016. Movements and activity levels of juvenile American lobsters Homarus americanus in nature quantified using ultrasonic telemetry. Marine Ecology Progress Series 551: $155-170$.

National Oceanic and Atmospheric Administration (NOAA) National Marine Fisheries Service. 2019. Letter in response to Vineyard Wind Offshore Wind Energy Project, Lease Area OCS-A-501, offshore Massachusetts Essential Fish Habitat (EFH) Assessment from April 19 and 29, 2019. Letter prepared by Louis A. Chiarella, Assistant Regional Administrator for Habitat Conservation, NOAA. Submitted to Ms. Michelle Morin, Chief, Environmental Branch for Renewable Energy, Bureau of Ocean Energy Management (BOEM). June 27, 2019.

NOAA Fisheries greater Atlantic region habitat and ecosystem services division (NOAA habitat). 2020. Recommendations for Mapping Fish Habitat. January 2020. Available on request.

O'Hara, C.J., and R.N. Oldale. 1980. Maps showing geology and shallow structure of eastern Rhode Island Sound and Vineyard Sound, Massachusetts: U.S. Geological Survey Miscellaneous Field Studies Map MF-1186, 5 sheets, scale 1: 125,000.

Pearce, B., J.M. Farinas-Franco, C. Wilson, J. Pitts, A. deBurgh, and P.J. Somerfield. 2014. Repeated mapping of reefs constructed by Sabellaria spinulosa Leuckart 1849 at an offshore wind farm site Continental Shelf Research 83: 3-13.

Pearson, T.H., and R. Rosenberg. 1978. Macrobenthic succession in relation to organic enrichment and pollution of the marine environment. Oceanography and Marine Biology: An Annual Review. 16: 229-311.

Poppe, L.J., K.Y. McMullen, S.J. Williams, and V.F. Paskevich, eds. 2014. USGS East-Coast sediment analysis: procedures, database, and GIS data. U.S. Geological Survey Open-File Report 2005 1001. Version 3.0. November 2014. https://woodshole.er.usgs.gov/ openfile/of2005-1001/. Accessed 23 January 2019. 
Rhoads, D.C., and L.F. Boyer. 1982. The effects of marine benthos on physical properties of sediments. In Animal-sediment relations, ed. P.L. McCall and M.J.S. Tevesz, 3-52. New York: Plenum Press.

Rhoads, D.C., and J.D. Germano. 1982. Characterization of organismsediment relations using sediment profile imaging: an efficient method of remote ecological monitoring of the seafloor (REMOTS system). Marine Ecology Progress Series. 8: 115-128.

Roper, C.F.E., M.J. Sweeney, and C.E. Nauen. 1984. FAO species catalogue, Vol. 3 cephalopods of the world. An annotated and illustrated catalogue of species of interest to fisheries. FAO Fisheries Synopsis 125 (3): $1-277$

Saskov, A., T.G. Dahlgren, Y. Rzhanov, and M. Schlappy. 2015. Comparison of manual and semi-automatic underwater imagery analyses for monitoring of benthic hard-bottom organisms at offshore renewable energy installations. Hydrobiologia 756 (1): 139153

Schlappy, M., A. Saskov, and T.G. Dahlgren. 2014. Impact hypothesis for offshore wind farms: explanatory models for species distribution at extremely exposed rocky areas. Continental Shelf Research 83: $14-23$.

Selgrath, J.C., K.A. Hovel, and R.A. Wahle. 2007. Effects of habitat edges on American lobster abundance and survival. Journal of Experimental Marine Biology and Ecology 353 (2): 253-264.

Sheehan, E.V., T.F. Stevens, and M.J. Attrill. 2010. A quantitative, nondestructive methodology for habitat characterisation and benthic monitoring at offshore renewable energy developments. PLoS One 5 (12): e14461.

Shields, M.A., L.J. Dillon, D.K. Woolf, and A.T. Ford. 2009. Strategic priorities for assessing ecological impacts of marine renewable energy devices in the Pentland Firth (Scotland, UK). Marine Policy 33 (4): 635-642.

Shumchenia, E. 2011. Developing benthic monitoring protocols for offshore renewable energy impacts. Presentation at the Coastal and Estuarine Research Federation Meeting, Daytona, FL.

Shumchenia, E.J., S.L. Smith, J. McCann, M. Carnevale, G. Fugate, R.D. Kenney, J.W. King, P. Paton, M. Schwartz, M. Spaulding, and K.J. Winiarski. 2012. An adaptive framework for selecting environmental monitoring protocols to support ocean renewable energy development. The Scientific World Journal 2012: 1-23. https://doi.org/ 10.1100/2012/450685.

Shumchenia E., M. Guarinello, D.A. Carey, A. Lipsky, J. Greene, L. Mayer, M. Nixon, J. Weber. 2015. Inventory and comparative evaluation of seabed mapping, classification and modeling activities in the Northwest Atlantic, USA to support regional ocean planning. Journal of Sea Research.

Skipjack Offshore Energy, LLC (SJOE). 2020. Construction and Operations Plan, Skipjack Wind Farm. Prepared by Stantec, Laurel, MD. Submitted to the Bureau of Ocean Energy Management, Sterling, VA. Revision 3. July 2020.

Smith, B.E., J.S. Collie, and N.L. Lengyel. 2011. Chronic bottom fishing, the invasive ascidian Didemnum vexillum, and Demersal fish feeding: the "pros" and "cons" of habitat alteration on northern Georges Bank. American Fisheries Society $140^{\text {th }}$ Annual Meeting. Conference Paper.

Szulecki, K., S. Fischer, A.T. Gullberg, and O. Sartor. 2016. Shaping the 'energy union': between national positions and governance innovation in EU energy and climate policy. Climate Policy 3062: 1-20.

Taylor, P.D., and M.A. Wilson. 2003. Palaeoecology and evolution of marine hard substrate communities. Earth-Science Review 62 (1-2): $1-103$.

U.S. Army Corps of Engineers (USACE). 2013. Engineering and Design - Hydrographic Surveying. Manual No. EM 1110-2-1003. https:// www.publications.usace.army.mil/Portals/76/Publications/ EngineerManuals/EM_1110-2-1003.pdf?ver=2014-01-06-155809307. Accessed 23 January 2019.

Valentine, P.C., J.S. Collie, R.N. Reid, R.G. Asch, V.G. Guida, and D.S. Blackwood. 2007. The occurrence of the colonial ascidian Didemnum sp. on Georges Bank gravel habitat - ecological observations and potential effects on groundfish and scallop fisheries. Journal of Experimental Marine Biology and Ecology 342 (1): 179-181.

Voormolen, J.A., H.M. Junginger, and W.G.J.H.M. van Sark. 2016. Unravelling historical cost developments of offshore wind energy in Europe. Energy Policy 88: 435-444.

Wahle, R.A., and R.S. Steneck. 1991. Recruitment habitats and nursery grounds of the American lobster Homarus americanus: a demographic bottleneck? Marine Ecology Progress Series 69: 231-243.

Wilding, T.A., A.B. Gill, A. Boon, E. Sheehan, J. Dauvin, J. Pezy, F. O’Beirn, U. Janas, L. Rostin, and I. De Mesel. 2017. Renewable and Sustainable Energy Reviews 74: 848-859.

Wilson, J.C., M. Elliott, N.D. Cutts, L. Mander, V. Mendao, R. PerezDominguez, and A. Phelps. 2010. Coastal and offshore wind energy generation: is it environmentally benign? Energies 3 (7): 13831422 . 